\title{
Why Analyze Immigrants? Ethical and Empirical Aspects ${ }^{1}$
}

\author{
LARS ØSTBY, M.Sc. \\ Senior Research Fellow, Statistics Norway
}

\begin{abstract}
The Norwegian pattern of international migration changed profoundly in the last part of the previous century. Norway is now an immigration country, with a significant immigration surplus from all parts of the world. This is a comparatively new phenomenon in Norwegian society. In accordance with Norwegian traditions, it called for research. During the last 10-15 years, the amount of statistics and analyses on immigration and immigrants has been growing, inside and outside Statistics Norway. Ethical aspects should be important, as this a very sensitive field. Questions have been raised as to the use of 'immigrant' as a permanent classification in analyses, comprising even persons who never immigrated themselves. The basic idea of this article is that as long as the concept of 'immigrant' is useful in revealing discriminatory practices, we have to carry out the analysis. Without knowledge of discrimination we cannot work effectively against it.
\end{abstract}

Keywords: Immigration, immigrants, integration, and ethics of social science

\section{Introduction}

A young boy of mixed African-Norwegian origin was killed in a suburb of Oslo in late January 2001. This triggered strong reactions in the public and media. Focus was directed at racism in a new way in Norway. In a television interview, His Majesty King Harald was asked what should be done to avoid such outrages happening again. He could, of course, give no precise answer, but he encouraged each and everyone to look into their heart to see if anything at all had been done to

1 This article is based on a Norwegian version, Østby (2001d), published by Statistics Norway (SN) in the journal Samfunnsspeilet 2/2001, available at $<$ http://www.ssb.no/samfunnsspeilet 200102 $>$, a thematic issue focussing on migration-related statistics and analyses. This issue is recommended for those interested in the topic and able to read Norwegian. I am particularly grateful to Stine Bjertnæs, guest editor of that issue and co-ordinator for immigration-related statistics at $\mathrm{SN}$, for encouraging me to write this article, and for constructive feedback on its content. I am also grateful to her successor, Benedicte Lie, for her valuable input on this English version. 
contribute, directly or indirectly, to such crimes happening, and to see if something could be done to prevent such outrages from being repeated.

Social scientists, like migration researchers, demographers and population statisticians should not be excempted from such appeals to evaluate their history, and neither should Statistics Norway (SN), as one of the main suppliers of empirical information on Norwegian society. As immigration in Norway has increased during the last decades, migration research has gained importance and volume. Correspondingly, in SN, the activity in the field of migration statistics has also increased.

From the early $19^{\text {th }}$ century, Norway was an out-migration country. Between 1865 and 1930, there were more out-migrants to overseas countries than from any other European country except Ireland. From 1930 to late 1960s, there was very moderate out-migration. However, almost every year since 1970 Norway has had net immigration, first due to demands of the Norwegian labour market, and from the mid-seventies, combined with a certain inflow of refugees and asylum seekers who were permitted to stay. Since 1967 , net immigration amounts to approximately 210,000 persons. The total population growth between 1967 and 2001 was close to 750,000 , so immigration is important.

During the last three decades, there has been net out-migration of approximately 40,000 Norwegian citizens, and net immigration of 250,000 foreigners. The net immigration from Western European countries has been closely related to the Norwegian labour market situation. Unemployment has remained at a comparatively low level, varying between two and six percent of the labour force. In periods of high unemployment (early 1980s and some years near and around 1990), immigration from Western Europe was low. The most significant immigration is related to refugees and asylum seekers. The numbers vary with crises, especially in the Balkans, and with Norwegian immigration policy. With its moderate population size (4.5 million inhabitants), Norway is by no means a major immigration country in the European context. Between 1996-2000, however, relative net immigration to Norway was second only to Ireland and Luxembourg in Europe (Vassenden 2001).

As a result of these processes, the stock of immigrants in Norway in the year 2000 is 282,000 (6.3 percent of the population, Statistics Norway 2001). In Norwegian statistics (Statistics Norway 1994), 'immigrant' is defined as a person born to two foreign-born parents. All statistics of this kind in Norway are based on population register data. Everyone living in Norway with an intention to stay for at least six months, and with a legal right to stay, is included in the register. There has been a rapid growth in the number of immigrants. In 1980, there were less than 100,000 and in 1990 there were 170,000. Fifty percent of the immigrants have a Third World 
background, less than 20 percent come from Eastern Europe and from other Nordic countries, and the remaining 12 percent come from Western Europe (the majority) and North America. For more information on the level and development of immigration to Norway, visit the web site of Statistics Norway (http://www.ssb.no/ english).

As registers are the basis for most population and social statistics in Norway, we can in principle do all relevant statistics and analyses in these fields by immigration background. Ethnicity, as we will see later, is no longer a variable included in any official statistics, or in analyses based on these sources. Ethnicity has also a limited use in other sources, mostly related to the Sami population. As examples of the main immigration projects in SN, we will mention demographic analyses (Østby 2001b), survey of living conditions (Blom 1998), labour market statistics and analyses (Blom 1996; 1997; Statistics Norway 2001a and b), social aspects (Lofthus and Osmunddalen 1998), criminality (Gundersen et al. 2000; Hustad 1999), income (Lofthus 1998; Bjertnæs 2000; Statistics Norway 2001c), spatial concentration among immigrants (Blom 1999), and works on discrimination (Østby 2001e) and integration (Østby 2001a and c).

Migration research in Norway has been co-ordinated by the Norwegian Research Council through a research programme called International Migration and Ethnical Relations (IMER) since 1991. Tesli (2001) gives an overview of this research. Based on priorities of what kind of information the society needs, and on agreements with the responsible government ministry, the production and analysis of immigration statistics in SN has increased in volume during the 1990s. As chairman of the IMER programme, and having been responsible for research on demography and living conditions in Statistics Norway for one decade, I find it pertinent to discuss in this article the role migration research and migration statistics might have for society and for the persons such research is focused on: immigrants.

In hindsight, surprisingly few questions have been raised as to what has been done in migration statistics and analyses over the last decades. Consequently, statisticians and researchers may have asked (too) few questions about the ethical aspects and consequences of their work. The statistical concepts that are basic in the standard classification of migrants seem to be widely accepted, although some of the designations (the labels we put on them) have met with indignation among some groups. Especially the term "second-generation immigrant" seems to be difficult to accept, as it denotes persons that have not immigrated themselves, but are children of immigrants (Bjertnæs 2001a). Are we putting too much emphasis on a group that already is often in the (negative) focus of the media and public opinion? Maybe immigrants have enough problems in Norwegian society as it is, without being analysed by social scientists in every detail? Are these problems only temporary, a result of transitory processes, with no need to undertake external efforts to solve them? 
Groups with a clear scepticism towards the prevailing immigration policy in Norway have accused Statistics Norway of withholding information, claiming that we know more about the negative consequences of immigration than we dare to publish. All priorities are of course set on a strictly scientific basis. It would be completely wrong if statisticians or social scientists used political reasons to not publish correct information that concerns society's need to obtain information. If analyses of a phenomenon, controversial or not, can be done on a sound, scientific basis, and the analyses are needed as a basis for decision-making, it is even more important that we provide relevant information. The work has to be developed in close co-operation with the main users, as they are the true experts on users' need, but the decision based on scientific criteria lies with the scientists alone.

\section{Statistics have to be relevant}

What we produce has to be relevant, or else we should not produce it. But the appraisal of what is relevant, and what is not, will be rather different for different persons and groups. It is important that scientists and statisticians have strong enough analytical competence to make independent judgements with regard to relevance. Some topics will have a value of their own, independent of users' interests. We cannot abstain from describing central aspects of society, regardless of whether we have defined user interests or not.

Close to 60 percent of the population increase of 250,000 in the 1990 s can be directly or indirectly attributed to immigration. There has been net in-migration of 100,000 , and, in addition, the excess of births over deaths in the immigrant population amounts to almost 50,000 (for an analysis of immigrant fertility in Norway, see Lappegård 2000). The high - in a European context - population growth in Norway (see Council of Europe 2001) is the combined result of high fertility in the national population and high immigration.

For the Oslo metropolitan area the importance of all this is even higher. The population growth of the city of Oslo was 55,000 (12 percent) in 1988-2000. The growth in the immigrant population of the capital accounted for 87 percent of the population increase: non-western immigrants alone were responsible for 80 percent of the total growth. Thus, to understand national and regional population growth, we have to understand migration.

New differences in living conditions and class structures have emerged in Oslo and in the rest of Norway. These changes have to be understood in the context of immigration. Not only immigrants themselves, but also to some extent their children born in Norway, typically encounter difficult living conditions. Some even say that immigration creates a new, permanent underclass, a class structure that will be transferred from one generation to the next (Wikan 1995). For others, the children 
of immigrants are on their way to the top of society (immigrant youth cited in the newspaper Aftenposten 09.02.2001). Social scientists have a clear obligation to identify and understand such processes.

\section{User needs must be met, and so do the needs of the general public}

We have to listen carefully to requests from the public, and keep in mind the main user needs. The public's needs might be difficult to identify, and they might be so numerous and so various that it is not easy to react to them. Immigrants are also a part of this public. The media often present the needs of the public, whose perspectives on immigration are more often negative than positive. Immigrant crime comes immediately in focus every time immigrants commit serious crimes. General problems involving immigrants and others are often given a specific immigrant perspective. In producing statistics, we are faced with the dilemma that relations that we know are quite complicated have to be oversimplified in indicators, tables and texts. Such simplifications can be further "tabloidised" by secondary users in media or elsewhere. By presenting analyses rather than pure numbers, it is easier to avoid misuse of results.

The main users of information can often have their needs for statistics and analyses met simply by paying for the work needed to develop it. These needs often coincide with the needs for information that society in general has, but this is not always the case. A serious problem is that in periods of generally increasing market dependency, public needs that are not articulated by groups who have the ability to pay will not easily be met. The public will seldom have resources to develop new statistics; they can only influence the priorities set by authorities. Consequently, there is a risk that information will no longer be a free commodity, but will be more readily available to those who can pay than to others. In a world where the public sector is being scaled down, this will probably be a growing challenge for statistics as well as social research, and a threat to the functioning of the democratic society - an issue that does not attract enough attention.

\section{Is it stigmatising to be in focus?}

For a person who does not feel welcome in a society, or even feels excluded, it will probably be an extra burden to be the focus of the attention of the media, researchers etc. This might be the case even if the focus is on the group as such and not on each individual member of the group, even when the perspective is not a negative one. For that reason, research conclusions must always be presented with due consideration to the feelings of the members of the target group. Wrongly presented, it is easy to see that statistics and research can have a stigmatising effect.

It is, however, important not to abstain from collecting information or to withhold important conclusions. If we can conclude that the people with the highest income 
are paying relatively less in taxes than people with lower income, this could be the basis for revising the tax system to retain its intension to be progressive. Highincome groups will suffer from the change, but they cannot course prevent this information from being public.

\section{"Do we describe or construct reality?"}

Hansen (1999) discusses the fact that social research always puts people in categories. He also discusses the terms that are used for describing life courses and living conditions by raising the question cited above. He emphasises that different terms and alternative categorisations can provide a basis for different conclusions. Much that is negative can be said about placing unique individuals into broad categories, and about not having the ability or will to exploit all available information about a person. In statistics, however, we have to use aggregate figures, look at averages, do regressions, analyse differences between groups etc., but always we have to carry with us the understanding that what we present is an oversimplification of reality, and that a sound understanding of society needs to be based on different approaches to groups as well as to individuals.

\section{Do we understand immigrants as individuals, and not only as members of a group?}

In a conference on migration and integration at Statistics Sweden, February 2001, Mona Sahlin, the Swedish minister responsible for immigration questions, underlined the necessity to analyse the immigrant as an individual, not just as a member of a group. This stance is of course difficult to argue, but for social research, it cannot be the supreme guideline for everything that we do. We are dependent on making categories, but we should always be mindful of the influence we have on the public's understanding of reality when we define our categories, concepts, terms, and analytical approaches. Putting unique individuals into broad groups with few nuances is what our descriptions and analyses are based on. We cannot avoid it, but we can do it in a responsible way. As statistician, I am glad that we have other groups like anthropologists, biographers, storytellers, and writers who can depict an individual in all her complexity.

Very often, our descriptive and analytical categories have to be mutually exclusive: you are either an immigrant or not an immigrant. In this lies the invitation to think of "them" as a group different from "us". But no more than we think of "us" as a homogeneous group without internal differentiation do we believe "them" to be homogeneous. The categories should not be loaded with more content than what is simply needed to establish them, but we are not able to control the connotations and associations they awake.

One might, however, exaggerate the importance that statistical concepts have for individual emotions, and for the formation of public opinion. We could discuss the 
degree to which problems like social exclusion are caused by the concepts and terms we use in empirical research, and the degree to which the problems are caused by the underlying, ugly reality. Especially the term "second-generation immigrant" encounters severe criticism for excluding from society persons who have never have lived in any other country. Already William Shakespeare commented on this relevantly when he described the smell of a rose as independent of the name we have given the flower. Discrimination of immigrants smells as bad as it ever did, even if we say "person with a minority background", or "person born abroad", instead of saying "immigrant".

\section{Do statisticians think all immigrants are identical, since they put them all in one group?}

Statisticians, probably more than others, are aware of the fact that the group "immigrants" is too heterogeneous to be relevant for analytical purposes. In the very acknowledgement of this lies the need for much and detailed information on immigration. Immigrants in Norway have only one common feature: their background is in one of the more than 200 countries of the world, encompassing the poorest and the richest, and the least and the most developed. For most distributions, immigrants will have a much wider span than non-immigrants. It is necessary to subdivide immigrants according their backgrounds. Sex, age, social background, social class and all other variables normally included in social analyses also apply to immigrants, just like they do to the rest of the population. In addition, we have to know where they are from and how long they have been in the country to follow and understand their process of integration.

Further, it is of outmost importance to understand why immigrants come. Did the reason have to do with distress or something positive? Was it because of another family member, or for personal reasons? The possibilities of a labor migrant are completely different than those of an immigrant who fled war and persecution, even if they come from the same country. A person who arrives to start or resume family life will have a different experience of Norwegian society than a person without any prior contacts. Our categories should be guided by relevance for analysis, not by considerations of what is politically correct.

\section{Does the inclination to put people into categories serve any purpose?}

Since statisticians continue to do so, it must be the opinion of the majority of us, and I share this opinion. Blanck (2000) writes in an article entitled "Ethnic categories counteract discrimination" (my translation from Swedish) that positive preferential treatment of minorities counteracts discrimination, and to implement such a policy, and to monitor its effects, it is necessary to have an ethnic classification system. According to Blanck, this is an inevitable element in American statistics, but is met with strong counter-arguments in Sweden. The case is the same in Norway. 
Blanck's opinion seems to be that the terms we use - immigrant, integration, plurality - mirror the society in which they are created, and the implementation of new concepts is an attempt to influence this society. If we want increased integration in a multi-ethnic society, we have to answer these questions: Which ethnic groups are present in the country, and what effects does ethnicity have on performance in the labour market or on the educational system? To be able to answer, we need relevant statistics.

The article by Blanck is based on a work by Åsard and Runblom (2000). They summarise the experience of preferential treatment in Sweden and the United States. Preferential treatment can be justified through its effect on removing "unproportionate" differences. Åsard and Runblom state $(2000,6)$ that such treatment has to be based on relevant categories, precise statements of goals, and a precise description of the population and labour force along relevant variables. Further along the same lines, Østby (2001e) states that without a decent measure of discrimination, we will not be able to evaluate the work done against it.

\section{Should we register ethnicity?}

For the time being, we have no statistics on ethnicity in Norwegian statistics, but it was an element of the censuses until 1970 (for a discussion, see Søbye 1998). There are serious objections to ethnic registration, and moreover, Statistics Norway lack the legal basis for it. National background is as relevant as ethnicity for many purposes, and that information is included in our register-based statistical system. We do not know whether an immigrant coming from the U.S. (American citizen, born in the U.S.) has a white, Afro-American or Hispanic background, but for many purposes we do not need to know this. Neither do we know much about groups that lack a nation-state, like Kurds. In the case of those who come from regions with ethnic conflicts, knowledge of their ethnic background could be useful.

The Norwegian census included questions on ethnicity for more than 100 years up to 1970 . The aim of this registration was to have information on the Sami and Finnish populations. There was eventually a declining need, and also an acceptance of these questions. Because of an increasing awareness among the Sami about their position as an indigenous population, there are again requests to resume this kind of registration. It may seem a little paradoxical, but can be understood as a reflection of the need to be visible, which is often experienced by minorities. It is probably relevant to the rights of the Sami to the natural resources in their area if there are 10,000 or 100,000 Sami in Norway.

Haug (2000) reports on work done by the Council of Europe on the demographic characteristics of national and immigrant minorities. His basic attitude is that, for a number of reasons, ethnicity is not well suited to demographic purposes. The basic reason for this work on minority demography is the right of each minority to been 
visible. In a statistical context, that means to be defined and counted. This is not at all uncontroversial in Europe where some countries do not even recognise the existence of minorities within their territories, where others have serious political problems with how they should be treated, and where problems related to human rights are often raised.

For most of the aims that population statistics are meant to serve, ethnicity need not be a variable; country of birth is sufficient for immigrants themselves, and parental country of birth for their children. In the following, I will try to illustrate the reasons for our choice of concepts by applying them in some simple analyses.

\section{Some Norwegian empirical examples}

So far, we have tried to give reasons for why there is a need for detailed statistics on immigrants, in the same way as there is for many other groups in society. The purpose is to give a nuanced description of social differences, and to monitor social processes. If we followed the well-intentioned advice to not focus on immigrants, or to "accept" the inclusion of second-generation immigrants in the national population without registering their living conditions, we would not have the possibility to follow the process of integration into Norwegian society of persons with a foreign background. The aim is not to merely describe the misery of the immigrants. On the contrary, a picture that is richly nuanced will contain positive as well as negative elements. Even when we are demonstrating large differences between immigrant groups, or when we give a negative picture of a phenomenon, it would not be right to suppress it, if it is an element in a relevant description.

\section{The concept of integration}

One of our main perspectives in integration. In my opinion, it is a necessary condition for being integrated in Norway that one can provide for oneself and one's family with earned income. A discussion of this can be found in Østby (1997). Only in exceptional cases can immigrants of an active age feel themselves full members of Norwegian society, and be considered as such by others as well, if they are permanently dependent on income transfers for survival. Seen in this way, the labour market will be the main arena of integration. While education often provides the ticket to the labour market, education is also an important area.

\section{Unemployment varies, but is often} disproportionately high among immigrants

For a long time, Statistics Norway has monitored unemployment among different groups of first-generation immigrants, and observed how it varies with the economic fluctuations and duration of stay in the country. For detailed information on this, 
see Bjertnæs (2001b), Holter (2000) and Statistics Norway (2001b). On average, immigrants from the Nordic countries, the rest of Western Europe and North America experience the same level of unemployment, and as the trend follows closely the national average for Norway (very low in a European context). For these groups, duration of stay in the country has no effect.

Figure 1. Registered unemployment as a percentage of the labour force, according to country of origin. End of November 1988 to 2000.

\section{Percent}

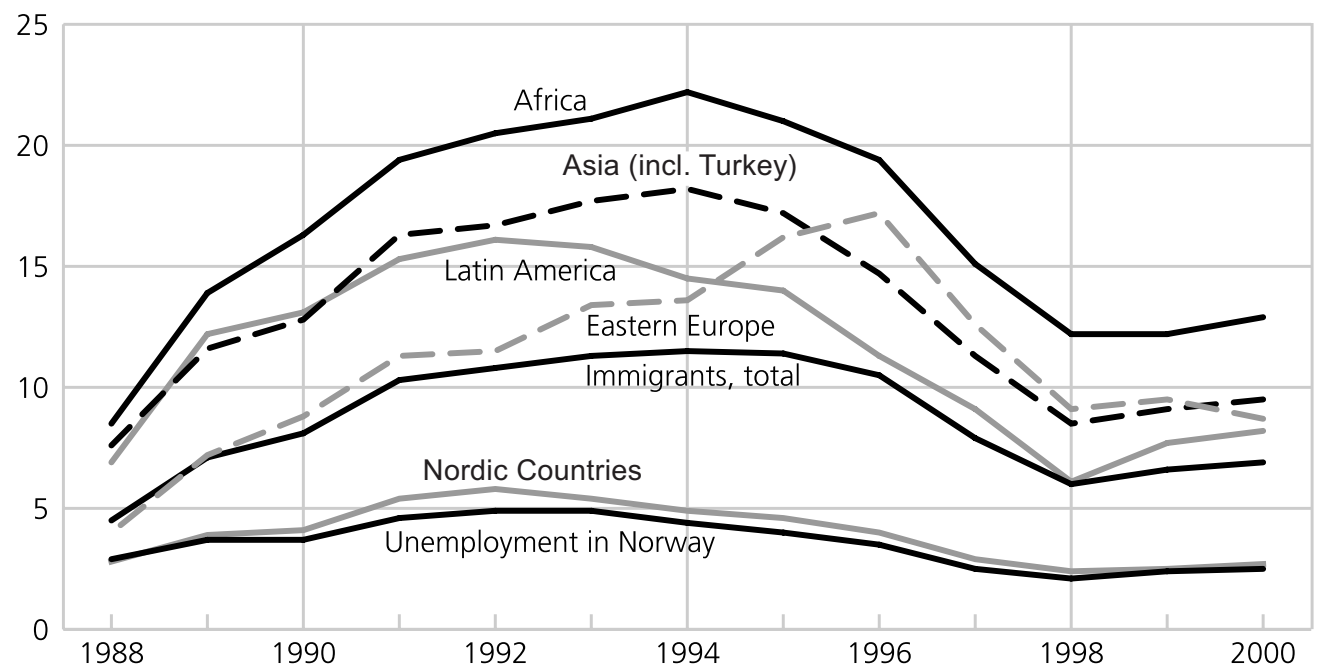

Source: Labour Market Statistics, Statistics Norway.

Immigrants from non-Western countries show a completely different picture. Among them, unemployment is three to five times the average rate (see Figure 1). When unemployment rises as recession first begins, it starts first among non-Western immigrants, and when the economy revives, this group is also the last to experience an improvement in labour market conditions.

Unemployment depends strongly on the national background of the immigrants. An African background translates into higher unemployment than an Asian or Latin American background. These differences are stable through economic fluctuations, but the rate varies according to the labour market situation, and with the average duration of stay of each group. Within each region, there are large differences between countries of origin. By and large, it is more difficult for immigrants from Somalia and Iraq than for others to find work, whereas unemployment among immigrants from Sri Lanka and Chile is comparatively low. These differences can be partly explained by differences in background and in ethnic networks in Norway, but discrimination is obviously also a part of it. 


\section{Labour force activity varies in the same way as unemployment}

The registered number of the unemployed offers only a partial picture of the labour market situation of a particular group; there are also significant differences in activity rates. Labour force activity is measured as the percentage of members of a group who worked during a reference week. Self-employment is not yet included, but we have seen indications that the main patterns would be the same if it were included. As the age distribution of immigrants and natives differs so much, we will make the comparisons using broad age groups.

Among immigrants from non-Western countries, the proportion of those who are employed is lower than among Western immigrants and those who have not immigrated (Figure 2). We find this pattern in all age groups. Closest to the average come young men from Asia. They have lower rates of education, and consequently more of them are available to the labour market.

Figure 2. Proportion of employed first-generation immigrants, by region and age. Percent. Males and females, $4^{\text {th }}$ quarter 1999.

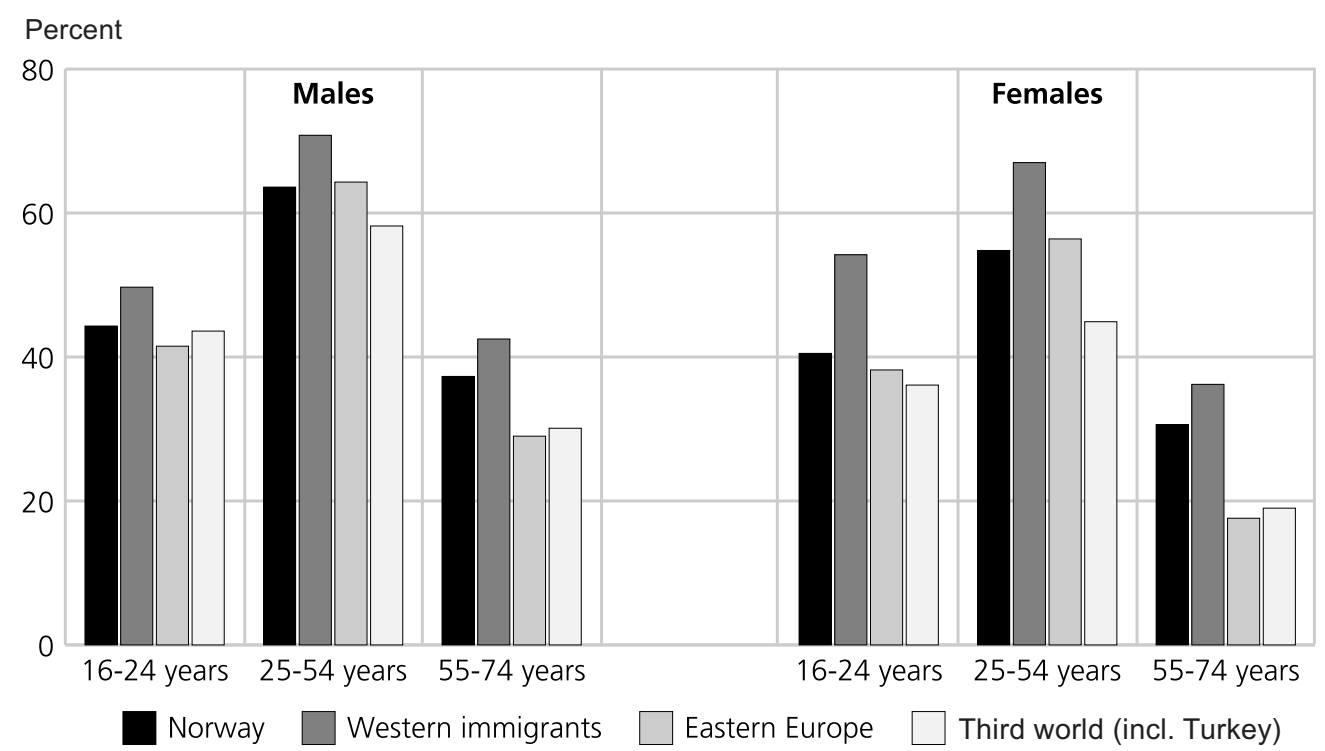

Source: Labour Market Statistics, Statistics Norway.

The gender difference in employment rates is bigger among non-Western immigrants than among other groups. The largest differences are found for ages 25-54. This may be related to differences in labour force activity among women with underaged children, but we are unable to verify this with our data. For the older age group (55-74 years), the differences between immigrants groups, and between immigrants and non-immigrants, are rather small. 
Refugees have a looser relation to the labour market than other immigrants from the same regions. There are a number of reasons for this. Refugees often have few or no contacts in Norway before arrival; their experiences in the home country may have been very traumatic: their home country is often very different from Norway in all aspects; etc. As we could hope, these differences do decline with duration of stay (Bjertnæs 2001b; Østby 2001a), for example, with the help of refugee integration programs. But not all differences disappear completely. The situation in Norway at the time of arrival also seems to be important. Those who arrive when the demand for labour is high seem to have a permanently better labour market situation than those who arrive during a period of high unemployment (Blom 1997).

But even for refugees, the situation improves with duration of stay. Mathiesen (2001) shows an employment percentage of more than 60 for refugees from Sri Lanka and Chile. For refugees from Vietnam, the employment rate has increased from 29 to 42 percent in two years, and for those from Somalia, from 21 to 27 percent.

\section{Educational activity is more frequent among second than first-generation immigrants}

Education is very important in attaining a position in the labour market, and consequently, for integration. We often read stories in newspapers about highly educated non-Western immigrants, who often received their education in Norway, but who are unable to find a job even after sending out hundreds of job applications. In spite of this sad fact, labour force participation is increasing with increasing education (Blom 1998). 
Figure 3. Proportion of people aged 16-18 years who were in secondary school as percent of the cohort. 1 September 1997.

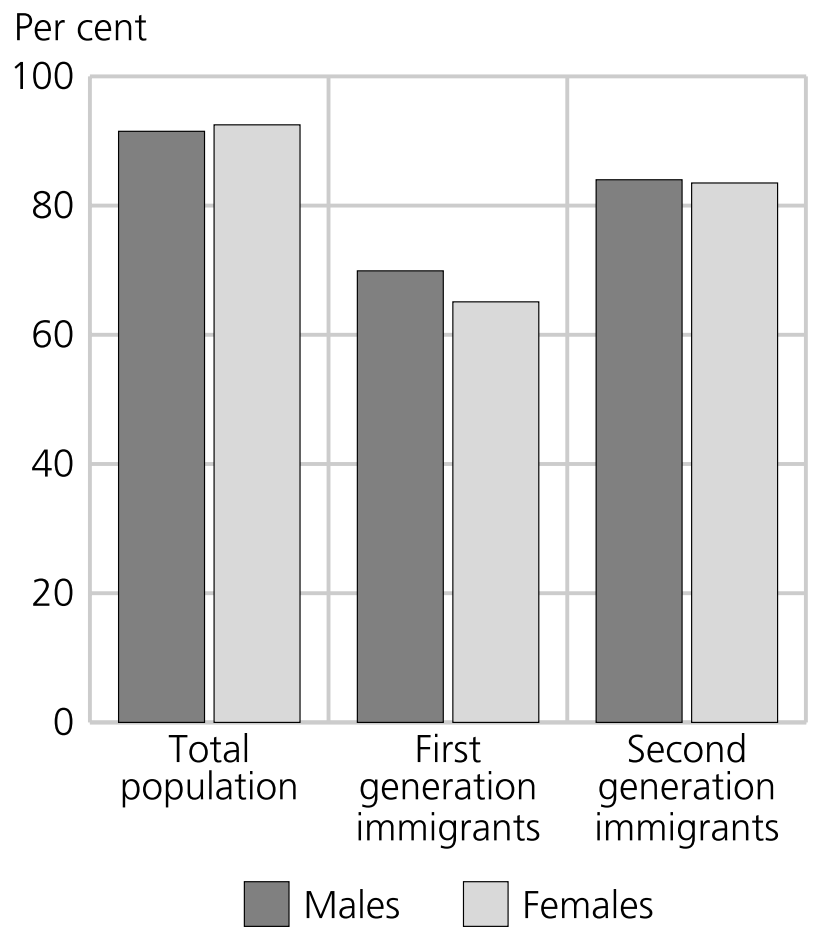

Source: Education Statistics, Statistics Norway.

Figure 3, like the rest of these paragraphs on education, are taken from Hauge (2000). The figure shows that in the total population, 92 percent of those between ages 16 and 18 were in secondary school in 1997. Among those who had immigrated themselves, 68 percent were in secondary school, whereas the percentage was 84 among those born in Norway with two foreign-born parents. The great majority in the last group have a non-Western background. Second-generation immigrants have considerably higher schooling frequency than those born abroad. Among all pupils in Norway, schooling rates are a little higher among girls than boys. For secondgeneration immigrants there is no difference, but among the first generation, schooling frequency is five percent higher among boys than among girls.

Among those leaving primary school in 1994, 97 percent continued directly on to secondary schools. This percentage was 92 for second-generation immigrants and 89 among those born abroad. There is no difference according to regional background, but among those who had lived in the country less than four years when they left primary school, 25 percent left the educational system. 
Another interesting indicator is the proportion of those who completed the threeyear secondary school successfully within four years after leaving primary school. Second-generation immigrants worked their way through the educational system considerably quicker than the first generation, in addition to having a higher participation rate.

\section{Income depends greatly on duration of stay in Norway, and there is great variation between groups}

It is rather complicated to analyse immigrant income in Norway in a way that would make comparisons between groups relevant. Østby (2001a) discusses this, and we shall refer to some simple comparisons here. In Figure 4, we are comparing two groups of non-Western immigrants, those who come to Norway as refugees, and others. Both groups include only first-generation immigrants.

Figure 4. Average social assistance, wage income and total income in 1997 for nonWestern refugees and non-refugees, by year of arrival 1986-1997.

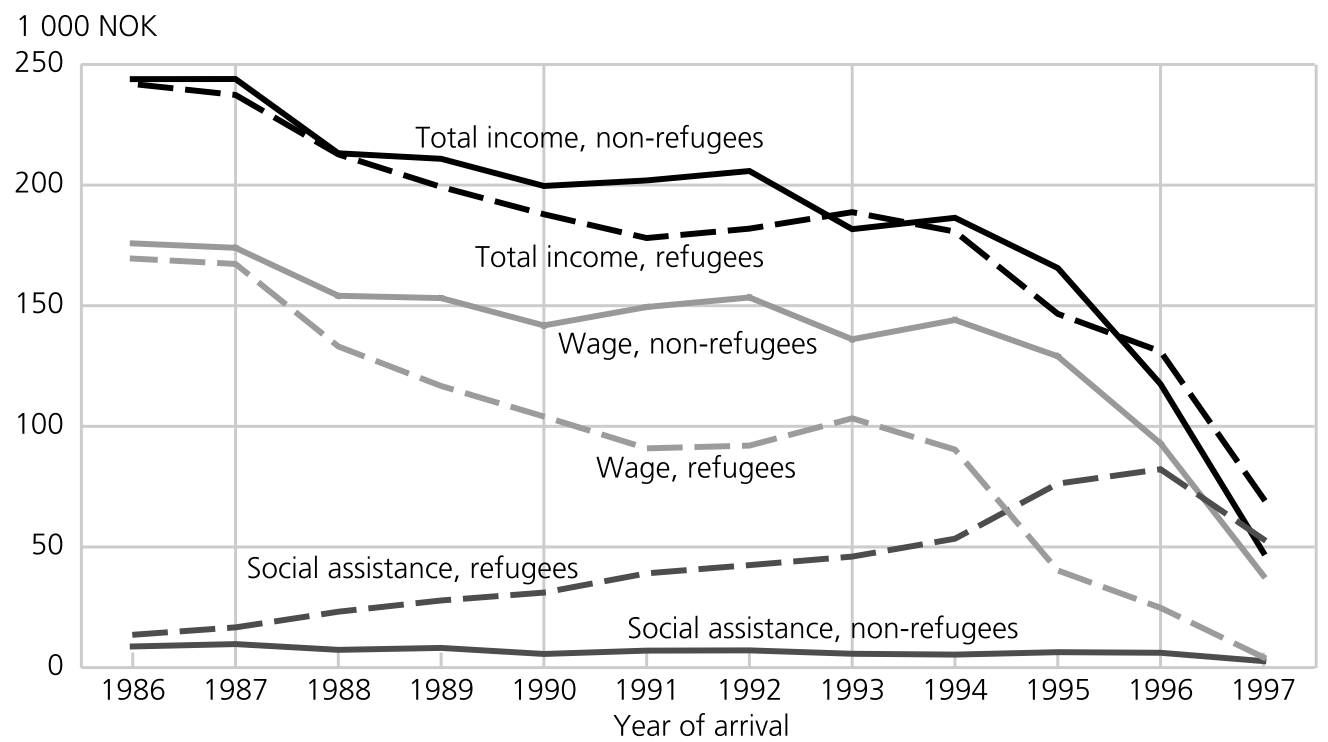

Sources: Population Statistics and Income Statistics, Statistics Norway.

The figure shows social assistance, wage income and total income for refugees and for non-refugees of non-Western background. Income is calculated for 1997 for each immigrant cohort back to 1986. There are large differences between refugees and others, especially during the first years after arriving in Norway. This might not be strange, taking the very different conditions of the two groups into consideration. When refugees arriving in 1993 have higher income than nonrefugees from the same year, the reason is that the majority of refugees in 1993 were Bosnians, a group that for several reasons was very easily integrated into the 
labour market. For those who have been in the country since the 1980s, the income difference is negligible. This might indicate that differences between refugees and non-refugees are, after all, not permanent.

Even with the significant differences between refugees and non-refugees, there might be still greater differences between different groups of refugees. Without going in detail, we will only refer to Østby's finding (2001a) that when for refugee families coming from Somalia it took ten years before their income from work was higher than their income from social assistance, refugees from Sri Lanka had a higher income from work than from social assistance already in the year of arrival.

\section{Is it more important to analyse immigrants than to refrain from doing so?}

We will now return to the question raised in the introduction: Why is there so much attention on immigrants in statistics and research? Immigration is probably an expression of one of the most important processes of change going on in contemporary European societies. It is closely linked to globalisation, and is politically controversial. Clearly, each citizen has a need to know about and understand these processes to be able to form an opinion and participate in the democratic decision-making process. Individual immigrants arrive in a society that can, to a limited degree, receive him or her in a way that makes the encounter as unproblematic as possible. It is important to test the assumption that we are creating a new underclass. To be able to do this we need the kind of data and analyses presented in this article.

\section{It is important to evaluate whether or not political goals are being met}

Based on general ideals on equity that are important elements of our political system, various Norwegian governments have had immigration policies that have been based on limited and controlled immigration. Also according to these ideals, immigrants who are allowed to stay in the country should have the same rights and obligations as all other members of our society. One of the main messages in white paper No. 17 (1996-97) on immigration and a multicultural Norway is this: "Integration, equality of status and participation in a multicultural Norway is a prerequisite for society having access to the resources and experiences of immigrants" (KAD 1996,7). It states further that “... It is an aim to ensure that new social differences, following the division between persons with immigrant background and the rest of the population, will not come into being" (op. cit., 7-8). These and other statements in the government's immigration policy platform (op. cit., 7-9) include an implicit assumption that there can be an empirical evaluation. 
For population statistics, it is of course important to follow the yearly flows of migrants into and out of the country. There is nothing controversial about this. But it is also important to follow up on the conditions of those who are allowed to stay. It is an aspect of society that we cannot neglect in our descriptions and analyses, and it represents a knowledge basis for decisions made by central and local authorities. It will also form the empirical basis for important immigration research.

\section{Integration: Equal rights, opportunities or outcomes?}

In the Statistics Sweden conference in February 2001 that was mentioned earlier, integration was defined as a question of equal rights in society. This is an important, but not the only aspect of integration. In addition, one can also define integration with regard to equal opportunities, or equality in outcomes, not necessarily equal outcomes. To be able to evaluate integration based on whether or not immigrants have the same possibilities as others to choose their future, our analyses have to include all relevant variables. The same applies when we are researching whether differences in outcomes are caused more by differences in tastes and preferences than differences in opportunities. Without being able to define and follow immigrants statistically, the effects of the policy cannot be evaluated.

To understand the trajectory immigrants follow in Norwegian society, and to be able to alleviate their situation if integration is too difficult, we need to understand how these processes develop, and what influences them. Such information must be very detailed, as immigrants are as heterogeneous as any other group. To understand these processes, we have to know where people came from, what their reason for moving was, and how long they have been in the country. We also have to know whether they have a family here or not, if this family was formed after arrival in Norway, if it was with a person whose background in the immigrant's home country or not, whether this person had already been in Norway for a long time, the kind of education they brought with them, and what education they have received after arrival etc. In short, we have to have the same information for immigrants as we normally have for all other groups in social analyses. If the social scientist closes her eyes from the complexity of immigration, she also loses the possibility of understanding what is happening.

\section{Can they never get rid of their immigrant label?}

Is it really necessary not only that people who once immigrated to Norway will remain in the category of "immigrant" their whole lives, but also that even their children are categorised as second-generation immigrants? This last group consists of persons that really have never migrated anywhere. It is in no way necessary to label the children of immigrants as immigrants, especially if such labels are considered exclusionary and as counteractive to successful integration (Bjertnæs 2001a). I am not sure what harm these labels do, but if they are offensive to some 
(maybe not the majority, see Samora 2001), they should be replaced by something better.

What we should not give up is the possibility to monitor the situation of immigrants and those born in Norway to two foreign-born parents in areas like education, the labour market, income, and living conditions in general. As long as information about a person's immigration background gives us significant information about the possibilities this person has in Norwegian society, this is a very relevant category in our statistics and analyses.

If we refuse to show the ways in which society is sorting its members into different classes, we are not protecting immigrants from "statistical discrimination"; we are protecting society from knowledge and understanding of its own discriminatory processes. Maria-Paz Acchardio from the Swedish Labour Organisation (LO) said at the Statistics Sweden conference that in order to counteract unfairness in society, the minimum that is required is to know about the unfairness that takes place.

It is very difficult to stop discriminatory practices, but without making it possible to describe them, without knowledge of their magnitude and distribution, how they occur and who their victims are, it is certainly not possible to counteract them. If society someday reaches a state where immigrant status, either one's own or that of one's ancestors, has no relevance for one's chances in life, it will be a pleasure to stop having to conduct the kinds of analyses described in this article. That day seems in a rather distant future, and the life expectancy for a male aged 57 is probably not high enough to ever see that day.

\section{References}

Bjertnæs, Marte Kristine. 2000. Innvandring og innvandrere 2000. (Immigration and immigrants 2000). Statistiske analyser 33. Statistisk sentralbyrå, Oslo-Kongsvinger.

_ 2001a. Når ordene teller. (When words matter). Samfunnsspeilet 2:15-20.

- 2001b. Innvandring og innvandrere 2001. (Immigration and immigrants 2001). Statistiske analyser 33. Statistisk sentralbyrå, Oslo-Kongsvinger. Update of Bjertnæs (2000) available on $<$ http://www.ssb.no/english/subjects/02>.

Blanck, Daniel. 2000. Etniska kategorier motverkar diskriminering. (Ethnic categories counteract discrimination). Innvandrare och Minoriteter 4.

Blom, Svein. 1996. Inn i samfunnet? Flyktningkull i arbeid, utdanning og på sosialhjelp. (Into the society? Refugee cohorts in labour market, education and on social assistance) Rapporter 96/5. Statistisk sentralbyrå, Oslo-Kongsvinger.

— 1997. Tracing the integration of refugees in the labour market. A register approach. In The Siena Group Seminar on Social Statistics, "On the way to a multicultural society?" Neuchatel, Switzerland, June 5-6, 1997:137-67.

_. 1998. Levekår blant ikke-vestlige innvandrere i Norge. (Living conditions among nonwestern immigrants in Norway). Rapporter 98/16. Statistisk sentralbyrå, OsloKongsvinger. 
- 1999. Residential Concentration among Immigrants in Oslo. International Migration, 37(3):617-41.

Council of Europe 2001. Recent demographic developments in Europe. Council of Europe publishing, Strasbourg.

Gundersen, Frans, Ulla Haslund, Arnt Even Hustad and Reid Jone Stene. 2000. Innvandrere og nordmenn som offer og gjerningsmenn. (Norwegians and immigrants as perpetrators and victims). Rapporter 2000/18. Statistisk sentralbyrå, Oslo-Kongsvinger.

Hansen, Erik Jørgen. 1999. Beskriver eller konstruerer vi virkeligheden - eksempler fra social forsknings klassifikationer. (Do we describe or construct reality?). Social Forskning, Temanummer dec. -99. Socialforskningsinstitutet, København.

Haug, Werner. 2000. National and immigrant minorities: problems of measurement and definition. Genus LVI(1-2):133-147.

Hauge, Ingvild. 2000. Barn og unge med innvandrerbakgrunn. (Children and youth with an immigrant background). Aktuell statistikk March 2000. Statistisk sentralbyrå, OsloKongsvinger.

Holter, Magne. 2000. SOPEMI Norway 2000. Upublished note, Kommunal- og Regionaldepartementet, November 2000. Available at

http://www.dep.no/krd/engelsk/publ/rapporter/016041-220011/index-dok000-b-n-a.html.

Hustad, Arnt Even. 1999. Begår innvandrere mer kriminalitet enn andre? (Do immigrants commit more crimes than others?). Samfunnsspeilet 3:2-8. Statistisk sentralbyrå, OsloKongsvinger.

Kommunal- og arbeidsdepartementet (KAD). 1996. Om innvandring og det flerkulturelle Norge. (White paper on immigration and multicultural Norway). St meld nr 17 (199697).

Lappegård, T. 2000. Mellom to kulturer (Between two cultures). Rapporter 2000/25, Statistisk sentralbyrå, Oslo-Kongsvinger.

Lofthus, Eivind (ed). 1998. Immigrants in Norway - A summary of findings. Statistical analyses 27, Statistisk sentralbyrå, Oslo-Kongsvinger.

Lofthus, Eivind and Åne Osmunddalen. 1998. Innvandrere og sosialhjelp - Får mer fordi de trenger mer? (Immigrants and social assistance - get more because they need more?) Rapporter 98/7. Statistisk sentralbyrå. Oslo-Kongsvinger.

Mathiesen, Bjørn. 2001. Flyktninger og arbeidsmarkedet 4. kvartal 1999 (Refugees and the labour market. 4th quarter 1999). Notater 2001/11. Statistisk sentralbyrå, OsloKongsvinger.

Samora. 2001. Hva i all verden skal vi kalle dem? (What on earth shall we call them?). Samora 4:16-9.

Statistics Norway. 2001a. Employee statistics for immigrants $4^{\text {th }}$ quarter 2000. Available from: $\leq$ http://www.ssb.no/english/subjects/06/03/innvarb en/>

- 2001b. Registered unemployment among immigrants $2^{\text {nd }}$ quarter 2001. Available from: http://www.ssb.no/english/subjects/06/03/innvarbl_en/ . 2001c. Income statistics for immigrants. 1998. Available from: http://www.ssb.no/english/subjects/05/01/inntinnv en/

Statistisk sentralbyrå. 1994. Nye tall for innvandrerbefolkningen (New data for the immigrant population). Ukens statistikk, 23.

Statistisk sentralbyrå. 2001. Innvandrerbefolkningen 1. januar 2000 (Immigrant population 1 January 2000). Aktuelle befolkningstall 13/2000 Available at $<$ http://www.ssb.no/english/subjects/02/01/10/innvbef_en/ $>$.

Søbye, Espen. 1998. Jødeforfølgelsene under den annen verdenskrig: Et mørkt kapittel i statistikkens historie? (Persecution of Jews, a dark chapter in the history of statistics?) Samfunnsspeilet 4:2-17. 
Tesli, Arne. 2001. Norsk innvandringsforskning i perioden 1991-2001. En forskningsstrategisk kartlegging og vurdering med vekt på Norges forskningsråds IMER-program. (Immigration research in Norway, 1991-2001). Norges forskningsråd, Oslo.

Vassenden, Kåre. 1997. Innvandrere $i$ Norge. Hvem er de, hva gjør de og hvordan lever de? (Immigrants in Norway. Who are they, what are they doing, how are they living?) Statistiske analyser 21. Statistisk sentralbyrå, Oslo-Kongsvinger. For an abridged English version, see Lofthus 1998).

- 2001. Hvor stor er innvandringen til Norge? (What is the size of immigration to Norway?). Samfunnsspeilet 2:33-41.

Wikan, Unni. 1995. Mot en ny norsk underklasse. (Towards a new Norwegian lower class?) Gyldendal, Oslo.

Østby, Lars. 1997. Measuring indicators of integration of immigrants. In: Swiss Federal Statistical Office (red): "On the way to a multicultural society". The Siena Group Seminar on Social Statistics, Neauchatel 5-6 June 1997:61-76.

—. 2000. Hva oppnår vi ved systematisk registrering, oppfølging og kartlegging (monitoring) av diskriminerende handlinger? (What do we obtain by systematic registration of discriminatory acts?) Presentation on a UDI-seminar on discrimination 3.10.2000. English version available Autumn 2001.

- 2001a. Beskrivelse av nyankomne flyktningers vei inn $i$ det norske samfunnet. (Description of the trajectories of recently arrived immigrants in the Norwegian society). Notat for Lovutvalget, KRD. Notater 2001:23. Statistisk sentralbyrå, Oslo-Kongsvinger.

- 2001b. Demographic characteristics of immigrants in Norway. Country case study for Council of Europe group of specialists on the demographic characteristics of immigrant populations. To be published by Council of Europe, 2002.

- 2001c. Flyktningers sekundaerflyttinger under 1990-tallet (Secondary migrations of refugees during the 1990s) Rapporter 2001/22. Statistisk sentralbyrå, Oslo-Kongsvinger.

- 2001d. Hvorfor fokusere på innvandrerne? (Why this focus on immigrants?). Samfunnsspeilet 2:2-14.

- 2001e. What do we achieve by systematically recording and monitoring discriminatory acts. Paper presented at Workshop 46 at the Sixth International Metropolis Conference, Rotterdam 26-30 November, 2001

Åsard, Erik and Harald Runblom 2000. Positiv särbehandling i Sverige och USA. (Affirmative action in Sweden and the U.S.) IMER - Social forskning 4:5-6. 